\title{
SOCIAL SERVICES IN CAPE TOWN: AN ANALYSIS USING THE POLITICAL ETHICS OF CARE
}

\author{
V Bozalek, N Henderson, W Lambert, K Collins \& S Green
}

\section{INTRODUCTION}

At the time of South Africa's transition to a constitutional democracy in 1994 the African National Congress (ANC) government inherited a deeply divided racially-based social welfare service system. Accordingly, the first priority of the newly elected government was to develop social policies to address the inequalities resulting from the apartheid period and to redirect resources to previously disadvantaged groups, especially black South Africans, since the white community had been the main beneficiaries of specialised professional services and institutional care (Bozalek, 1999; Follentine, 2004; Orner, 2003; Sevenhuijsen, Bozalek, Gouws \& Minnaar-McDonald, 2003a; Republic of South Africa, 1997). The ANC's election manifesto, its Reconstruction and Development (RDP) policy, had committed the government to a number of strategies to meet people's basic needs and to alleviate poverty and inequality, among them were employment creation; a living wage for all citizens; the democratisation of state structures; housing provision; and land redistribution (Republic of South Africa, 1994). The Constitution reinforced these commitments in its recognition of socio-economic rights, including the rights to adequate housing, health care, food, water, education and social security. The Human Rights Commission and other independent bodies, such as the Gender Commission, were set up by the Constitution to monitor human rights violations. There were expectations that social services would deliver on the social and economic rights outlined in the South African Constitution (1996) within the available resource constraints (Republic of South Africa, 2006).

In 1996 the ANC government replaced the RDP policy, which was intended to service the needs of the poor and vulnerable with a market-driven, neoliberal, growth-oriented macro-economic policy, with the Growth, Employment and Redistribution (GEAR) strategy (Streak \& Poggenpoel, 2005). In line with the International Monetary Fund (IMF) and its structural adjustment programmes, GEAR encouraged fiscal discipline on the part of the state and relied on the "trickle-down effect" to redistribute societal resources more equitably. The government created the impression that, as a result of globalisation and in order to ensure economic stability, there was no option but to conform to the prevailing international market trends set by the IMF. The shift from the RDP to GEAR and more recently to ASGISI signalled a change from social justice and redistribution to neoliberal concerns with fiscal restraint, and control of inflation and interest rates as well as trade and financial liberalisation (Aliber, 2001; May, 2003). GEAR has been the target of a considerable amount of criticism from the NGO sector, church leaders and the trade union movement, who accused the government of reneging on its commitment to meeting basic needs as outlined in the RDP. GEAR elicited deep concern in the light of widespread poverty and inequality in South Africa. Besides the significant political gains and improvements in social services since 1994, South Africa is still rated as one of the most unequal countries in the world, with 45 percent or 18 million of the population of 47 million living below the poverty datum line (Zegeye \& Maxted, 2003; Aliber, 2001; De Swardt, 2001). The poorest group are African female-headed households in rural areas, about 17 percent of which are headed and maintained by grandmothers (Aliber, 2001; Lund Committee, 1996; Taylor Committee, 2002).

Despite an avowed commitment to social development, South Africa's welfare policy is still premised on the Calvinistic work ethic and a residual service system, where welfare operates as a safety net for those who are under- or unemployed, especially vulnerable groups with special 
needs, such as the disabled and elderly (Tronto, 1994). The White Paper for Social Welfare (Republic of South Africa, 1997) proposed a two-tier system based on this work ethic. On the one hand, it suggested a system of cash transfers, social relief and developmental services to provide protection during times of unemployment, ill-health, maternity, child-rearing, widowhood, disability and old-age, so that households could adequately care for their members and, on the other, it advocated a system based on the human and social rights of vulnerable groups of people with special needs who were unable to participate in the economy. In this way, it was envisaged that social welfare would not only contribute to social development, but would also lead to social integration. The White Paper for Social Welfare (1997) also claimed that the proposed system would secure basic welfare rights, equity, non-discrimination (in terms of tolerance, mutual respect, diversity and inclusion), democracy (in terms of consultation and participation) and respect for constitutional human rights and fundamental freedoms, as well as "people-centred policies", investment in human capital and fundamental freedoms, sustainability, transparency, accountability, accessibility, appropriateness and lastly ubuntu, the African concept of caring for each others' wellbeing. These were ambitious goals given the weaknesses in the system that was inherited by the ANC government.

\section{THE SHIFT TO DEVELOPMENTAL SOCIAL WELFARE}

The shift to an ill-defined social developmental approach envisaged by the White Paper for Social Welfare (1997) was confirmed when the National Department of Welfare and Population Development became the Department of Social Development (Sevenhuijsen et al., 2003a; Streak \& Poggenpoel, 2005). This was followed by a document on Financing Policy for Developmental Social Welfare Services (Republic of South Africa, 1999) spelling out the changes in social service delivery as set out in the White Paper. The financing policy called for an increased emphasis on prevention rather than remedial care, and a paradigm shift away from a focus on pathology and specialisation to a developmental, integrated anti-poverty focus. The needs of vulnerable groups, such as children, young people, families, women and older persons, those living with HIV and AIDS, and substance-abuse problems, and generally living in poverty were seen as the main priorities for social service delivery. However, this financing policy and its successor, the 2004 Policy on Financial Awards to Service Providers, were both vague on the role of NGOs and the government sector in service delivery and on the way that these services were to be funded. According to NGO critiques of the 2004 document, it underplayed the under-funding of developmental welfare services, particularly in the NGO sector (Streak \& Poggenpoel, 2005).

The Department of Social Development's recently released Integrated Service Delivery Model (Republic of South Africa, 2006) goes somewhat further in identifying the types of services envisaged by developmental social welfare, although what exactly is meant by this remains unclear (Streak \& Poggenpoel, 2005). The document identifies two major types of delivery, namely social security and social services, and notes a predominant focus on social security since 1994, which consumes over $90 \%$ of the welfare budget for social assistance payments, such as the old age pension, child support and disability grants. This skewed focus has led to the curtailment of some social welfare and community development services and the neglect of others. From April 2005 the administration of social security payments was handed to an independent agency with its own budget. This has led to a renewed interest in the working conditions of social service workers, the nature of the services offered and the need to prioritise developmental social services (Republic of South Africa, 2006).

These developmental services would largely focus on "Social processes that bring about changes in relationships so that the poor, vulnerable and marginalised can gain increased control over their 
lives, and access to and control over resources" (Republic of South Africa, 2006:16). Five categories of service are identified: promotion and prevention services; rehabilitation services; protection services; continuing care services; and mental health and addiction services. The values are based on Batho Pele, a term in the seSotho language meaning People First and include equity and freedom from discrimination in the workplace and in social services; partnerships; use of resources in effective and innovative ways; transparency and accountability; sharing knowledge and expertise; and application of the Constitution to practice (Republic of South Africa, 2006:1416). Batho Pele seeks to apply these principles by calling on social service organisations to deliver quality services which are responsive to user needs.

\section{THE CRITICAL ETHICS OF CARE PERSPECTIVE}

What is clear from these three major policy documents - the White Paper for Social Welfare (Republic of South Africa, 1997), the Financing Policy: Developmental Social Welfare Services (Republic of South Africa, 1999), and the Integrated Service Delivery Model (Republic of South Africa, 2006) - is that developmental social welfare is premised upon a work ethic ${ }^{1}$ and aspires to creating a normative citizen who is self-reliant or independent, autonomous and economically engaged. For example, the White Paper for Social Welfare (Republic of South Africa, 1997) proposes that "innovative strategies ... for vulnerable individuals and families to increase their capacity to earn a living through employment creation, skills development, access to credit and where possible through facilitating the transition from informal to formal employment". Using the work ethic as a moral framework, it is assumed that the deserving poor are those who wish to work, but are unable to find employment. Rather than locating the problem in the political economy of the country, the capacity or lack thereof to earn a living is located with individuals and families. Political and feminist ethics of care approaches are critical of using the work ethic as a moral framework and use the lens of the ethics of care to make judgements about social policies. From the lens of the ethics of care, social policies are judged in terms of the extent to which they acknowledge the centrality of care in human lives and hold that all human beings need care at some point in their lives. Citizens can only acquire autonomy through public and private assistance with their needs, as they find themselves in positions where they both need and have to give care at various points in their lives. Thus, political ethics of care approaches assess social policies and social service delivery from the perspective of human interdependence and vulnerability. Governments, from this perspective, should distribute resources so that those who are involved in public and private care-giving are able to meet needs.

Tronto (1993) sees "care" as a social and moral practice and as distinctive from other activities such as production, marketing, leisure activities and creative pursuits, in that it takes as a starting point the perspective of others' needs. As a practice, professional care involves engagement with the well-functioning self (of the service provider), others (service users) and the material life context (Sevenhuijsen, 2002: personal communication). This is not new to social work, which has long advocated the social worker's use of self, client interests and the social environment as integral to helping or care. Fisher and Tronto (1990) identify four essential care-related activities with four attendant areas of skill:

\footnotetext{
${ }^{1}$ According to Tronto (1994), two major assumptions for moral and political life flow from the work ethic: one is desert - what people deserve is what they have worked for to obtain - if you work hard you will get what you need; and the second is that the desert is individual rather than collective - you get what you deserve depending on how hard you yourself work. In the work ethic, work is seen as a virtue and the legitimate way of acquiring wealth and status - economic success is seen to be a measure of moral worth. If you work hard, you are judged as being morally worthy and those who do not work are seen as "other".
} 
- Caring about involves the moral attribute of attentiveness or realising or noticing that there is a need for care, and recognising that needs are culturally shaped. Attentiveness has also been recognised as a core skill in social work and has an aspect of mindfulness to it.

- Taking care of involves assuming some form of moral responsibility for the need of another once it is noticed, as well as responding to the identified need. Thus there is an element of carer responsiveness in the act of "taking care of someone".

- Care-giving involves the practice of meeting needs through physical acts rather than financial provision. Money is vital in supporting the care-giving activity, but more important morally is competence in the physical act of caring.

- Care-receiving involves the recipient's response to the care given, which requires that the person being cared for is responsive to the care received.

For Tronto (1993), these four caring activities are interlinked and should be part of an integrated care-giving process which needs to be implemented in a holistic manner. Sarah Banks (2006) incorporates this interlinking as a fifth element of a framework of care ethics and terms it integrity. Thus "knowledge of the context of the care process and making judgements about conflicting needs and strategies" (Banks, 2006:61) is crucial in assessment of the quality of human service delivery.

The Minister of Social Development claimed that social development policy in South Africa was premised on an ethic of care (Sevenhuijsen et al., 2003a). This is a valuable perspective for social development, since the moral values of responsibility, responsiveness, attentiveness and competence can provide a meaningful framework from which to analyse social service delivery. However, this implies that governments are motivated by moral rather than political considerations. The White Paper for Social Welfare (Republic of South Africa, 1997) has been critiqued from a political ethics of care perspective (Sevenhuijsen et al., 2003a). In this paper we also make use the political ethics of care, not to critique social policies, as the Sevenhuijsen et al. (2003a) article did, but to report on a joint research project which was conducted on social service provision and delivery.

Applying this framework to the White Paper for Social Welfare (1997), Sevenhuijsen et al. (2003a) critiqued its positioning of care as primarily the private responsibility of families and communities, rather than inhering in social values where human life is a priority and care is part of social responsibility and citizenship. If it is acknowledged that care is not just a private and individual or family responsibility and activity, but needs collective and public acknowledgement and responsibility; then care can be seen as a political activity. Extensive study of care provision within the social service sector in South Africa is needed. This paper offers some preliminary observations of care within a number of social service settings in the Western Cape, one of South Africa's nine provinces, resulting from an exploratory research project on welfare service provision.

\section{THE JOINT RESEARCH PROJECT}

In 2004 social work departments from three universities in the Western Cape, which covers 129,450 square kilometres and has a population of 4.5 million people, collaborated in a pilot project investigating the perceptions of social service providers. Eighty-nine students gathered data from 51 service points in the Western Cape. The project aimed to establish the kinds of services being offered to service users at organisations to which students had access; investigate service providers' views of the services offered and their views on the needs of the client population 
served; establish the conditions under which the service providers worked; and investigate service users' 2 experience of the services provided.

Service providers included volunteer counsellors, professional social workers, managers, child care workers, youth workers, and probation officers. They represented organisations in both the formal (government) and informal (church organisations, crisis counselling centres, welfare and community based organisations) welfare in the greater Cape Town and Cape Flats area of the Western Cape. Service providers were representative of the general population in South Africa.

Each student spent time at a particular organisation interviewing service providers. A standardised open-ended questionnaire based on the four moral values of the ethics of care developed by Tronto (1993) was used. Questions related to attentiveness (the services provided to clients, the social service providers' perceptions of clients' needs and problems), responsibility (the perceptions about who takes responsibility for meeting the needs, the resources needed for meeting the needs and who is responsible for acquiring these resources), and competence (the social service providers' perceptions about how well they can do their jobs in relation to the resources available, the working conditions, and the support they receive). Responsiveness was incorporated in the interviews with service users and will not be reported on in this article. In exploring attentiveness, we examined service providers' perceptions of the kinds of services offered by organisations; the personal services which service providers offered service users; the needs and problems of service users; and the means with which service users were able to survive under difficult circumstances.

\section{SERVICES PROVIDED BY ORGANISATIONS}

The services offered suggest that service providers paid particular attention to the protection of "vulnerable groups" as named in the White Paper for Social Welfare (1997). These services included caring, nurturing and trying to sustain human relationships. Children appeared to be the largest focus, which is in line with the Constitution (1996) and other policy documents in which children's needs are prioritised (Republic of South Africa, 1997; Republic of South Africa, 2006). The services were primarily aimed at children at risk, including the abused, neglected, ill or on the street (23\%). HIV and AIDS (13\%) were also targeted, and some of these services were aimed at AIDS orphans or children living with HIV and AIDS. General services were linked in some instances to foster-care placements for children. Crime was related to services (8\%) targeting young people at risk, as some organisations were engaged in diversion programmes that focused on diverting young offenders away from the prison system to programmes run by community providers. Children were also affected by domestic violence in the home, and family care included parenting skills as a priority. Drug abuse primarily affected children and was also a focus of three agencies.

\footnotetext{
${ }^{2}$ Service users were interviewed; however, for the purposes of this article the data resulting from these interviews are not included.
} 


\section{FIGURE 1}

\section{DESCRIPTION OF SERVICES PROVIDED BY ORGANISATIONS}

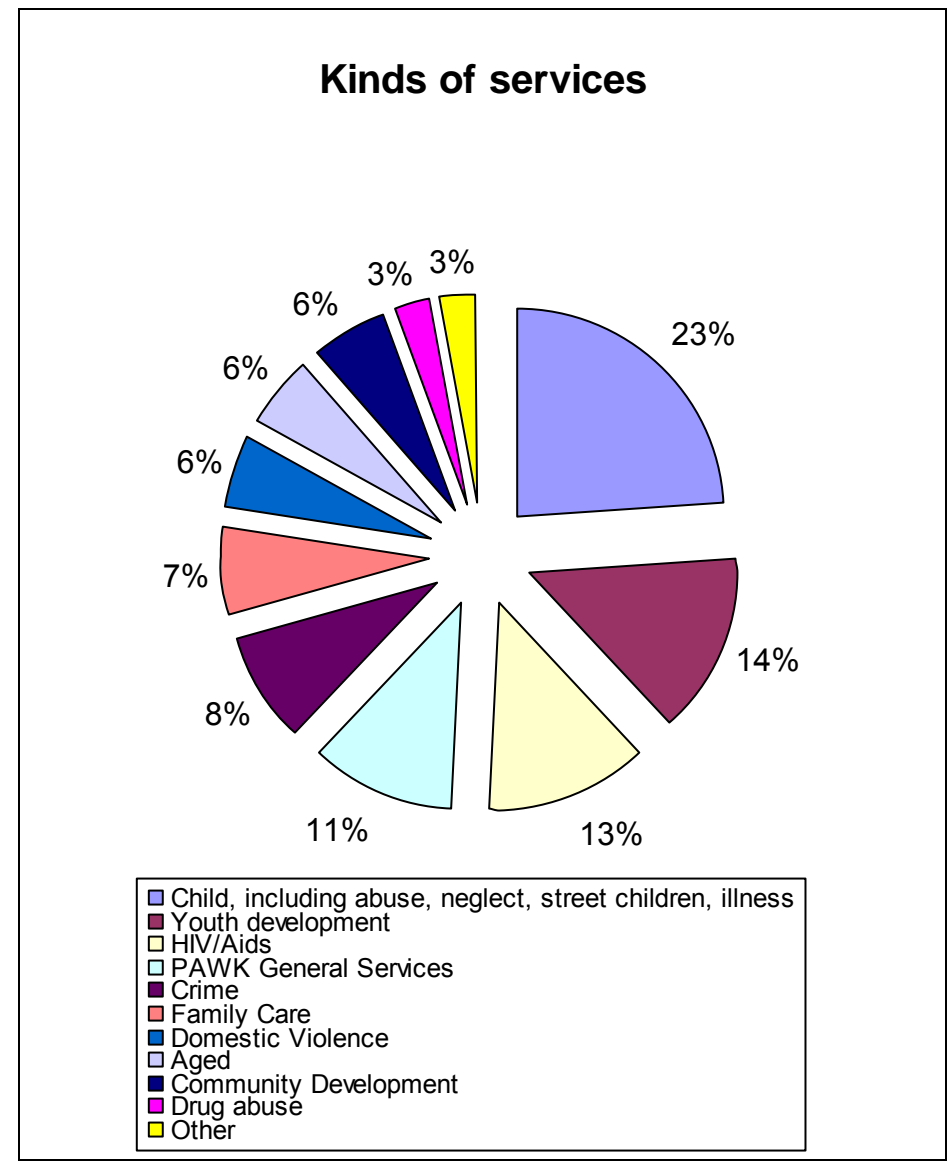

Figure 1 shows the main services provided by organisations. Counselling services appeared to be more of a priority than community work services. Very few service providers were engaged in community work $(10 \%)$. Respondents reported being involved in counselling (25\%), trauma debriefing (10\%), court preparation for children (9\%) and supervision of counselling volunteers (7.5\%). Foster-care placement (6\%) also involved counselling. Services for HIV and AIDS (14) included counselling and monitoring activities, and workshops and support groups. One respondent said: "Our work as counsellors is to engage with the client, as we provide advice through nutritional formula and check with our clients in terms of compliance and adherence with anti-retroviral therapy".

I see my work as a canalisation, administrative function which means that the child that has been placed in foster care or institutions, the court order expires after two years. The social worker would either recommend the child should remain in foster care or in a children's home or be reunited with his/her family. I submit an extension or discharge order.

We have four sections, intake, field, court and community ...Community deals with crèches and everything out there in the community. The whole department actually works with the 
community. If they need us, we all go out. For example, special weeks are set aside for certain aspects. I think it is now the weeks of child abuse and then we all go out there.

With regard to the way in which service providers viewed the needs of the client population they served, there was some agreement that basic needs must be addressed. Thirteen service providers identified financial need, thirteen unemployment and eleven saw food as a priority need. This links with the problems that were identified by respondents, such as unemployment (19), poverty (11), crime (6) and financial difficulties (4).

The need for victim support was linked to counselling on (i) domestic violence and legal options for abused women, (ii) child abuse, (iii) rape, and (iv) survival, medication and disclosure concerns relating to HIV and AIDS. Also pertinent in victim support programmes was dealing with gangsters and debriefing following traumatic experiences.

Youth development was regarded by service providers as another priority, especially dealing with drug and alcohol abuse and its impact on young people's development. Behaviour modification through life skills and sexuality programmes was seen as crucial to addressing risk behaviour in youngsters and encouraging safe sex practices. Also important was attention to love, care and emotional needs; counselling for child abuse, domestic violence and rape; the creation of new sport and recreational facilities for youth, general education and foster care issues. Problems affecting young people included poor parenting, marital tensions, illiteracy, teenage pregnancy, unsuitable living conditions (not suitable for large families) and homelessness.

Clients were perceived to be struggling to cope with unmet needs, surviving variously through the support of family and friends (9), state grants (7), the sale of vegetables, fruit and sweets (7), and through the love and care of community organisations (6). Five service providers said that clients were not surviving. Only three said they were coping well. The question therefore arises: whose responsibility is it to provide for client needs?

\section{RESPONSIBILITY}

For the most part service providers (17) believed it was the government's responsibility to provide more funding for the resource needed for effective service delivery. As one respondent put it:

Me, I must find it (resources) for my client. My employer is Government. But the Government does not provide me with enough resources. Definitely not. We wouldn't have poverty anymore. They are financially limited. But it does get better every year. There is more money available. When the debt is gone, then we will be more supported.

A wide range of resources was identified ranging from food parcels (9), to cars (8), to job creation (8), computers (7), grants (7), clothing (6); and office equipment like telephones (5), stationery (3) and fax machines (2). Buildings were also required as well as funds for their maintenance. Mentioned were youth centres (5), accommodation for the destitute (3), clinics (4), home for the elderly (2), houses (2), multi-purpose centres (2), schools (2), permanent building and offices (2), and churches (2). The need for human resources such as volunteers (3), police for crime prevention (3), nurses (2), social workers (2) and more counsellors was highlighted. In contrast to volunteers, they would need to be paid.

Regarding the organisation's access to resources to meet the needs of service users, the majority of the respondents said that they had access to resources (n-25). Only eight said that they did not. It was not clear whether funding was the primary reason why resources were not available, but it is highly likely to be the case. The service providers identified human resources (17) as the most readily available. Office equipment was also identified as a resource that is readily available. 
Telephones (11), computers (7), fax machines (4), photocopiers (4) and stationery (3) were seen to be available. However, six service providers were clear that resources were lacking. Four said that food parcels were available. Social workers (service providers) (18) were identified as primarily responsible for finding resources. Overall management, including project manager (5), fundraising team (5), director (5) and management (5) was also identified as being responsible for finding resources. More social workers (10) and funding (8) were needed. For clients important issues were job creation, food security, housing, and life skills:

Job creation is an important resource that is needed in the community.

If the clients can get a meal for the day ... a soup kitchen for the women can at least make some change in their lives.

Safe house(s) for children who are abused. Orphanage(s) for children who have been abandoned.

In need of life-skills to practice job interviews, writing skills. Our clients need to learn ways of dealing with conflict...

\section{Competence}

Pertinent to service providers' competence in service delivery is the conditions under which they worked and the support they received. For 15 service providers their working conditions were rated as favourable, whereas for seventeen they were not. Aspects of the work environment which were valued included support from colleagues (8), supervisors (7) and teamwork (10) as well as their social work training (7); a youth-friendly atmosphere, flexibility, good benefits and working conditions, such as a warm, caring environment, though only three reported the latter. Good benefits and rewards, according to one respondent, made up for high workloads and long working hours, provided there was "a good support structure from management". Less favoured was inadequate office space, high workloads, understaffing, conflict and unreliable clients, but most of all poor funding. Eighteen said there were both good and bad aspects of working conditions:

There is really no problem. I personally think we work in very good conditions, others may not agree. In terms of human resources, I am currently feeling the pinch. There is not enough person power, not with the work that needs to be done. Especially since we are closer the community than what we were five years ago. There is so much we can do now more than before. We have started to build up relationships with the community and need to maintain that. Idea of sustainability. Not happening enough. If we get another welfare planner, it would be easier. At the moment I am not only managing, I am doing the job as well. I don't have a choice.

The working conditions are quite challenging and stressful because I have to deal with three deaths on the same day, debriefing sessions, and HIV (and) AIDS clients as well. The workload is manageable. Sometimes I feel that I didn't offer $100 \%$ to certain wards because it's hectic to go there and I have to be in and out. Outpatient department is manageable as well.

What helps is when the client says thank you and is grateful for the work that the social worker is doing for them. It motivates the social worker to continue working and to continue to help others. It also helps when the results are apparent and the social worker can see that the client is willing to make an effort to change. It also helps when staff are thinking on the same lines and do not disagree. 
More money. Things outside office! Delays in Provincial office... Hierarchy/bureaucracy e.g. approval of funding to organisation. Gives them dates but then Provincial Government delays and promises are broken. People! They get upset and angry. Structure obstacles. Give four million to an organisation and it's overwhelming. The power and pressure to ensure that they deliver!

Support was mainly received from colleagues (24) and managers (10) with limited support from directors (3), consultants (4) and human resources department (2). The need for emotional support stemmed from the emotional toll of dealing with HIV and AIDS, domestic violence, trauma and child abuse, poverty and lack of basic needs. How then do service providers manage to survive in their jobs?

Being positive at all times (5) was one of the ways of surviving, according to service providers. Other keys to survival are praying to God (4), not to take work problems home (4) and the love of working with children (4). Relaxation (3) and passion for community work (3) were valuable aspects identified.

The fact that I am a community person within the community. I have been raised and born and work in the community. The other fact is that I get financial assistance from donors. This funding is used to pay the rent and salaries of workers. To be able to share and receive assistance from youth and the positive response from care receivers in the community.

I like working with people, so it comforts me to listen to someone telling their stories and seeing them leave better...Also by believing in resilience of people, in their ability to bounce back, their survival skills and ability to solve their problems.

Similar sentiments were expressed by service providers when asked what kept them going in their jobs. "You need to love what you are doing" (5) was identified as the primary reason for keeping going as a service provider. Passion (4) and faith in God (4) also contributed to them keeping going. Making a difference in the community (3), financial responsibility towards my family (3), motivation (3) and being valued by clients (3) were other important aspects mentioned.

Working in a hospital setting puts constraints on me. I cannot apply all my methods and get frustrated. I love social work and to help other people.

I am a believer and a Christian. My wonderful son keeps me going, my involvement in church activities. Through the community-based projects of which I take part as a member. Family outings on one Saturday of each month and praying.

Increased financial and more staff support (6) were identified by service providers as ideal support needed. More workers (3) and in-house caring sessions (3) were also identified as ideal support. One-on-one support from managers (2) was important as well. Service providers seemed to merely resign themselves to working conditions, because they probably knew that it was highly unlikely that resources would be provided for them.

More financial support to deal with organisation. Additional support for dealing with death and dying of clients. Psychological support to deal with staff conflict. Monitoring of security and efficient running of "our" homes.

There should be set procedures to allow us to manage and work. Things like relevant payment, financed leave. There should be encouragement given to us. That we can sustain the job. We need to meet the client's needs halfway. Things like poverty. Give people jobs, and create employment to fight poverty. 
A typical working day for service providers was "hectic", according to one respondent: "only get to plan of the day by $4 \mathrm{pm}$ ! Been there on a Saturday! Makes a difference. Lots of distractions. All work related and necessary".

Some quiet phone days, some crazy phone days! Can plan in advance and plans will go out of the window within half-an-hour of my day. Myth that we are lazy and take hours off. I don't even have time for lunch these days. Even if it was true, it can't happen now. Transparency!

Eight hours a day from $7 \mathrm{~h} 30$ - 16h00...Deal with problems and crises. Chair meetings! Handling tenants and running of complex. Act as link between tenants and various departments. Budgeting!

Examples of some who appeared less busy:

Prepare myself emotionally! Find a space to be quiet with introspection - work on my strength. Allow myself to relax and welcome that person. I write notes on form prepared. Client is asked if there are any issues to discuss. Clients need to come back, I set a date with the client.

I arrive at 8.00 and prepare to see clients at 8.30 in the morning. Finish the work from yesterday. After that start looking at the clients for the today. At $10.00 \mathrm{I}$ have tea and come back and see clients. Sometimes I will attend meetings and workshops. Lunch is at 1.00. After lunch I continue until $4 \mathrm{pm}$.

\section{IMPLICATIONS OF THE FINDINGS}

This paper opens service provision in Cape Town to public scrutiny and poses questions on the suitability and quality of care being provided to South Africa's citizens. It is our view that "care" is a social and moral practice with the ultimate goal of ensuring human flourishing (Nussbaum, 2001). Thus in examining the implications of our findings, we refer to each of the moral elements of the care ethic discussed earlier. This serves as a framework for our discussion of service providers' perception of the practice context. In the main, the service providers were social workers and this study, then, has implications for social work in South Africa. Essentially we were interested in the way in which service providers were able to perform their tasks and to engage with service users, their material life conditions and their experiences in this context. Importantly, the environment in which service providers operated affected their ability to provide quality care and to be attentive to client needs.

\section{Attentiveness}

Attentiveness might be understood by examining the kinds of personal services provided in accordance with the perceived needs and problems of service users. Given the extreme pressures under which they worked, also of interest was "self-care" and service users' survival strategies. Regarding the kind of services provided, there was a clear focus on the needs of vulnerable groups, especially vulnerable children: street children, AIDS orphans, and neglected and abused children. There is recognition that children have rights to a better life as highlighted in the South African Constitution and Batho Pele principles. There has also been a move away from the apartheid practice of keeping children in detention, where children were labelled as deviant or criminal. For example, diversion options are increasingly being used by the courts to keep children out of jail. However, the contemporary neoliberal political and economic environment also has its downside in focusing on dependent and vulnerable groups rather than on the needs of all citizens for protection from want and harm (Healy, 2005). Consequently, structurally induced material needs, 
such as unemployment, food, housing and clothes, become the main focus of services and most service providers are still "stuck" in the old paradigm of seeing clients as having "deficits" and communities as unable to "help themselves". One might say that attentiveness to poverty is being hampered by lack of resources. More particularly, community-based projects or projects that are community-centred are not only under-resourced materially, but lack guidance from social workers caught up in individual and family counselling rather than community development. Most importantly - for the ethics of care - service providers focused on the structural conditions of clients who were mostly "surviving by the skin of their teeth". However, the data do not reveal whether service providers viewed client need as structurally induced as a consequence of social, political and economic factors, which therefore required structural solutions. "Structural" seemed to imply resource provision and service providers were sure this was a government responsibility, especially since the South African government is the main provider of social welfare funding in partnership with the non-government sector.

\section{Responsibility}

Specific organisations (welfare service points) are supposed to implement responsibilities given to them through government policy. It is at national government level, within the government department of social development, where social managers (policy makers) operationalise processes for assessing needs on behalf of communities and identify gaps in the delivery of services. Social managers "claim the right to diagnose social problems and determine how they are to be treated" (Sewpaul \& Holscher, 2004:56). Services providers (district office managers, social workers and social auxiliary workers) provide "hands-on" delivery of social services (Tronto, 1999; Sewpaul \& Hölscher, 2004:82-85). It is this organisational arrangement of care which creates most conflict when resources are lacking. The divisions between policy makers and direct service providers in South Africa create much conflict, because social managers allocate and distribute financial resources for social services according to the finance policy which is premised on the neoliberal "logic of the market" principles. Social managers argue for fiscal austerity measures, where service delivery is measured within parameters of economic rationality. The reasons for this lie in the process of how budgets for social welfare are determined; the nature of programme classification for budget reporting; the priority afforded social welfare service spending; and the way in which government financial support for the non-government sector is processed. The most serious drawback of the financial policy is that it does not clearly describe the types of services, programmes and facilities to be funded: outputs and outcomes (deliverables and tangible results) are vague. Thus in our study service providers in both government and nongovernment organisations emphasised the lack of resources (human, financial and technical, in this order) to fully render services which would enable them to do their work effectively and efficiently, that is, competently, attentively and responsibly. They felt powerless and consequently were unable to affect the way in which resources were allocated. This was in the hands of managers in government (Sewpaul \& Hölscher, 2004). The situation seems unlikely to improve given the envisaged decrease - from $6.9 \%$ in $2000 / 1$ to $5.4 \%$ in $2006 / 7$ - in the welfare budget attributed to increases in spending on social security, such as disability and child support grants (Streak \& Poggenpoel, 2005). Another factor is the fiscal restraint advocated by the government's neoliberal economic policy and its promotion of black economic empowerment. In particular NGOs have been severely affected by inadequate funding allocations for services, including statutory services to children and families. Furthermore, according to Streak and Poggenpoel (2005:42), there are no plans by government to reverse the diminished priority accorded to social welfare services in the near future. 


\section{Competence}

Service providers, in responding to the research question on working conditions and what helps and hinders in their work with service users, described their own feelings of incompetence given the restricted means and resources provided for the delivery of services, because the financial policy "has not managed to support funding in line with need" (Streak \& Poggenpoel, 2005:41). Even though service providers were positive in terms of identifying some support systems in their organisations (working as a team, support from colleagues and supervisors), the lack of resources (including understaffing), big workload and limited office space appeared to impact substantially on workers' competence.

There still appeared to be a top-down approach in many organisations with the result that social workers sought support from other service providers and managers. In essence this was not unusual; however, the lack of communication and excessive bureaucracy, particularly in government services, impacted negatively on the implementation of services on the ground. Conflict amongst staff was also identified as a hindrance and this was probably due to affirmative action and personal agendas, which are likely to impact both positively and negatively on service delivery as welfare continues to grapple with transformation.

Service providers appeared to have a full day of activities, but it is not clear whether they were competent in the job. Some of their responses highlighted chaos, crazy days, problems and crises. Only a few talked of "being out in the community" or "doing community work", which again highlights their inability or lack of motivation to engage in social and community development. The question on how they spent a typical day was not fully answered by service providers, which might indicate that they felt vulnerable and perhaps defensive and did not wish to reveal much to students who interviewed them. In terms of service providers' responses to how they coped, passion, positive thinking, praying to God, making a difference in the community were all commendable ideals, but were hardly likely to make any dents in poverty and unemployment.

It has already been highlighted that the focus on counselling was not in line with the basic needs highlighted by service providers - financial need, unemployment, poverty and food insecurity which suggests that services provided are out of step with needs assessments. Service providers' hands are tied as a result of insufficient resources and the inability of government to increase resources and to implement strategies such as the Basic Income Grant. There is still a wide disparity between the haves and the have-nots in South Africa, and clients are indeed "surviving by the skin of their teeth".

\section{CONCLUSION}

This study has highlighted that service providers do adhere to the Batho Pele principles and do in fact construct needs as structural, but that the services they deliver are not directly addressing these needs. It is also apparent that fiscal constraints premised on neoliberal principles have negatively affected the responsibility and competence within care as a social and moral practice in service delivery. What South African policy such as the White Paper, the Finance Policy and the Social Delivery Model want to achieve is not possible for service providers to implement in their daily execution of tasks and responsibilities. The goal of the ethic of care is human flourishing within a material life context and, in such a context, the lived experiences of service users should be used as the premise upon which services are delivered. Instead, we find response that is acknowledged to be inadequate, approaching an ad hoc level and limited to only meeting the extreme needs of service users, by severely strapped service providers. 


\section{REFERENCES}

AFRICAN NATIONAL CONGRESS. 1994. The Reconstruction and Development Programme: A Policy Framework. Johannesburg: Umanyano Publications.

ALIBER, M. 2001. Study of the incidence and nature of chronic poverty and development policy in South Africa: An overview. Background Paper No. 3. Chronic Poverty Research Centre. University of the Western Cape, Programme for Land and Agrarian Studies.

BANKS, S. 2006. Ethics and values in social work. Basingstoke, Palgrave: Macmillan.

BOZALEK, V. 1999. Contextualising caring in black South African families. Social Politics, International Studies in Gender, State and Society, 43:85-99.

DE SWARDT, C. 2001. Unravelling chronic poverty in South Africa: Some food for thought. Background Paper No. 3. Chronic Poverty Research Centre. University of the Western Cape, Programme for Land and Agrarian Studies.

FISHER, B. \& TRONTO, J. 1990. Towards a feminist theory of caring. In: ABEL, E.K. \& NELSON, M.K. (eds) Circles of care: Work and identity in women's lives. Albany: State University of New York Press.

FOLLENTINE, S. 2004. Towards a common conceptual understanding of developmental social welfare and its implications for practice. Paper presented at the National Conference for Social Service Practitioners. Dialogue across Disciplines: Partnerships in Development. Pretoria, South African Council for Social Service Professions.

FRASER, N. 1989. Unruly practices: Power, discourse and gender in contemporary social theory. Oxford: Polity Press.

HEALY, K. 2005. Social work theories in context: Creating frameworks for practice. Basingstoke, Palgrave: Macmillan.

LUND COMMITTEE. 1996. Report of the Lund Committee on Child and Family Support. Pretoria: Government Printers.

MAY, J. 2003. Chronic poverty and older people in South Africa. Chronic Poverty Research Centre Working Paper. No 25.

ORNER, P. 2003. Race, gender and socioeconomic differentials in Social Welfare Policy: A case study of restructuring of the Social Maintenance Grant in South Africa. Social Work Practitioner-Researcher, 15(2):172-190.

REPUBLIC OF SOUTH AFRICA. 1996. Constitution of the Republic of South Africa. Act 108 of 1996. Pretoria: Government Printers.

REPUBLIC OF SOUTH AFRICA. 1997. White Paper on Transforming Public Service Delivery. Government Gazette No. 1834. Pretoria: Government Printers.

REPUBLIC OF SOUTH AFRICA. 1999. Financing Policy: Developmental Social Welfare Services. 26 March, No. 19888. Pretoria: Government Printers.

REPUBLIC OF SOUTH AFRICA, NATIONAL DEPARTMENT OF SOCIAL DEVELOPMENT. 2004. Policy on Financial Awards to Service Providers. Pretoria: Government Printers.

REPUBLIC OF SOUTH AFRICA. 2006. Integrated Service Delivery Model: Towards Improved Social Services. Pretoria: Department of Social Development. 
SEVENHUIJSEN, S. 1998. Citizenship and the ethics of care. Feminist considerations on justice, morality and politics. London and New York: Routledge.

SEVENHUIJSEN, S., BOZALEK, V., GOUWS, A. \& MINNAAR-McDONALD, M. 2003a. South African Social Welfare Policy: An Analysis of the Ethic of Care. Critical Social Policy, 23(3):299-321.

SEVENHUIJSEN, S. \& SVAB, A. (eds) 2003b. Labyrinths of care: The relevance of the ethics of care perspective for social policy. Ljubljana, Peace Institute.

SEWPAUL, V. \& HÖLSCHER, D. 2004. Social work in times of Neoliberalism: A postmodern discourse. Pretoria: Van Schaik Publishers.

STREAK, J. \& POGGENPOEL, S. 2005. Towards Social Welfare Services for All Vulnerable Children in South Africa: A Review of Policy Development, Budgeting and Service Delivery. Occasional Papers. Children's Budget Unit. Budget Information Service. Cape Town, Idasa.

Taylor Committee (2002). Transforming the Present, Protecting the Future: Report of the Committee of Inquiry into a Comprehensive System of Social Security for South Africa. Pretoria, Government Printer.

TRONTO, J. 1993. Moral boundaries: A political argument for an ethic of care. New York \& London: Routledge.

TRONTO, J. 1994. What's wrong with the work ethic. Unpublished paper presented to the Yale University Program in Politics, Economics and Philosophy.

TRONTO, J., FISHER, B. 1990. Toward a feminist theory of caring. In: ABEL, E. \& NELSON, M. (eds) Circles of care: Work and identity in women's lives. Albany: University of New York Press.

VAN EEDEN E., RYKE E. \& DE NECKER, I. 2000. The welfare function of the South African Government before and after Apartheid. Social Work/Maatskaplike Werk, 36(1):1-24.

ZEGEYE, A. \& MAXTED, J. 2003. Our dream deferred: The poor in South Africa. Michigan: Michigan State University Press.

Prof Vivienne Bozalek, Associate Professor and Chairperson, Mr Neil Henderson, fourth year fieldwork coordinator, Ms Wesley Lambert, part-time lecturer and supervisor, Prof Kathy Collins, Department of Social Work, UWC (formerly of UCT), Prof Sulina Green, Chair, Department of Social Work, Stellenbosch University, South Africa. 